\title{
Habitat use of the gnomefishes Scombrops boops and $S$. gilberti in the northwestern Pacific Ocean in relation to reproductive strategy
}

\author{
N. Takai* , Y. Kozuka, T. Tanabe, Y. Sagara, M. Ichihashi, S. Nakai, M. Suzuki, \\ N. Mano, S. Itoi, K. Asahina, T. Kojima, H. Sugita
}

Department of Marine Science and Resources, College of Bioresource Sciences, Nihon University, Fujisawa 252-0880, Japan

\begin{abstract}
The Japanese gnomefishes Scombrops boops and S. gilberti closely resemble each other but their geographical distributions in the northwestern Pacific Ocean are markedly different. In order to understand the determinants of reproductive isolation, we examined habitat use in relation to the reproductive strategy employed by these species in the Izu-Islands region, where adults of both species coexist. We examined the species compositions of the gnomefishes based on mitochondrial sequence differences, and the maturation process of gonads using the gonadosomatic index (GSI) and by histological observation of the gonads. Genetic analysis showed that large individuals ( $>400 \mathrm{~mm}$ SL) of both species were present in the region, whereas all small gnomefish (<400 mm SL) were identified only as $S$. boops. Thus, the Izu-Islands region is likely utilized as a nursery by $S$. boops but not by $S$. gilberti. The GSI of adult $S$. gilberti showed significantly higher values in March compared to the consistently low values detected for $S$. boops. In addition, the GSI-elevated $S$. gilberti had mature ovaries and testes. These results suggest that the Izu-Islands region is utilized as a spawning ground by $S$. gilberti but not by $S$. boops. It appears that $S$. boops spawns in the upper reaches of the Kuroshio Current and that the offspring are transported to the Izu-Islands region by the current. The differences between the species-specific spawning grounds, in conjunction with the transport provided by the currents, likely determine the interspecific differences in geographical distribution.
\end{abstract}

KEY WORDS: Reproductive isolation · Mesopelagic fish · Spawning · Nursery $\cdot$ Kuroshio $\cdot$ Izu • mtDNA $\cdot$ Geographical distribution

\section{INTRODUCTION}

The gnomefishes Scombrops boops and S. gilberti are commercially important species inhabiting the coastal waters of the Japanese Archipelago. Since the beginning of the 20th century, there has been speculation that these may actually be the same species because of the extreme similarity of their appearances (Tanaka 1931, Matsubara 1971, Yasuda et al. 1971). Recently, however, Itoi et al. (2008) found clear interspecific differences in the sequences of the control region and the 16S rRNA gene of mitochondrial DNA (mtDNA) for $S$. boops and $S$. gilberti, suggesting that these species are genetically different.

\footnotetext{
${ }^{*}$ Corresponding author: takai@brs.nihon-u.ac.jp
}

These fishes show similar life history patterns; both species inhabit the shallow waters in the sublittoral zone during the juvenile and young stages, and later move to the rocky bottom in the dysphotic zone at a depth of 200 to $700 \mathrm{~m}$ (Hayashi 2002). They are both carnivores, preying on fish, squid and shrimp (Mochizuki 1997). However, in contrast to the similarity in morphological characteristics and life history patterns, the geographical distributions of the 2 gnomefishes are markedly different. $S$. boops is broadly distributed, from the waters off southern Hokkaido (Japan) to Taiwan, whereas S. gilberti is found in a relatively narrow region of the Pacific from the waters off southern Hokkaido to the coastal

() The authors 2014. Open Access under Creative Commons by Attribution Licence. Use, distribution and reproduction are unrestricted. Authors and original publication must be credited. 
waters of the Izu Islands (see Fig. 1, Hayashi 2002). The interspecific difference in geographical distribution is more marked at the early life stages. The fishing grounds for young $S$. gilberti are mainly restricted to the coastal waters off the Sanriku coast, the northeastern district of the Japanese mainland. Young $S$. gilberti are rarely collected in the coastal waters of the Izu Islands, in spite of the abundant catch of adults there (Itoi et al. 2010). By contrast, young $S$. boops are broadly distributed along the Japanese Archipelago on both sides - the Pacific Ocean and the Sea of Japan (Itoi et al. 2010). At present, little is known about the reasons for such a marked interspecific difference in geographical distribution.

Recently, a few studies have presented genetic evidence to explain the disparate distributions of the 2 gnomefishes. Noguchi et al. (2012) sequenced the mitochondrial gene, cytochrome $b$, in $S$. boops collected from 7 sampling stations around the Japanese Archipelago and found that a single haplotype (a combination of alleles closely located on a chromosome or mitochondria) in each station. This suggested that $S$. boops consisted of a single population in this region, probably with a major spawning ground to the south of Kyushu Island (see Fig. 1). A northeastward transport of eggs and planktonic larvae born in the southern region by the Kuroshio Current and the Tsushima Warm Current could distribute $S$. boops throughout the Japanese Archipelago (see Fig. 1). On the other hand, Itoi et al. (2011) sequenced the cytochrome $b$ gene for $S$. gilberti collected from the coastal waters of the Pacific side of eastern Japan and showed that genetic differences were not significant between adults from the IzuIslands region and young from the Sanriku region. Itoi et al. (2011) presented the hypothesis that $S$. gilberti utilizes the Izu-Islands region for spawning and the Sanriku region as a nursery. The Kuroshio Current and its warm-core rings can transport eggs and planktonic larvae to the Sanriku Coast, although this transport system is somewhat unstable (Muto 1985). The results of these studies indicate that the geographical distributions of these gnomefishes could possibly be related to interspecific differences in reproductive patterns, including the location of the species-specific spawning grounds and the transport of eggs and planktonic larvae by ocean currents.

In the present study, we focused on the habitat use of these 2 gnomefish species in the Izu-Islands region. As mentioned above, the geographical distributions of the adults of the 2 species overlap in this region only (Itoi et al. 2011). If the inference by the genetic studies is correct, it can be assumed that the Izu-Islands region is the spawning ground for $S$. gilberti but not for $S$. boops. We examined the species compositions of the gnomefishes using a genetic discrimination method and the development process of the gonads in adults in the Izu-Islands region in order to understand their habitat use in relation to the reproductive strategy employed by these species in the region.

\section{MATERIALS AND METHODS}

\section{Life history of the gnomefishes}

Scombrops boops and S. gilberti are both largesized species, with adults reaching a maximum of $1 \mathrm{~m}$ or more in total length (Mochizuki 1997). Both species are considered to mature at a body size of about $380 \mathrm{~mm}$ total length when they are $3 \mathrm{yr}$ old (Mochizuki 1977, 1997). In captivity, the adults spawn isolated pelagic eggs with a diameter of about $1.2 \mathrm{~mm}$ and the larvae hatch about $3 \mathrm{~d}$ after the spawning in a rearing environment with a controlled water temperature of about $15^{\circ} \mathrm{C}$ (Yamada 1995). Juveniles settle on the rocky bottom in the shallow coastal waters after the planktonic stage, and remain near shore during the juvenile and young life stages. Their habitat shifts to deeper waters as they grow, with adults settling in the dysphotic zone at a depth of 200 to $700 \mathrm{~m}$ (Hayashi 2002).

According to Okiyama (1988) and Iwai (2005), their life history stages can be defined as follows. (1) Larva: fewer fin rays than the adults. (2) Juvenile: same number of fin rays as the adults, but with a markedly different external appearance from that of adults. (3) Young: external appearance similar to the adult form, but the proportion of some body parts differs from those of the adults. (4) Immature: external appearance almost the same as that of adults, but the gonads are not developed. (5) Adult: large body size and well-developed characters, with high reproductive ability.

\section{Fish sampling}

We performed 3 types of investigations (Investigation I, II, III) in the Izu Island region (Fig. 1) to examine (I) the temporal and spatial changes in species composition of the different sizes of gnomefish, (II) the temporal change in species composition of young gnomefish at a fixed station, and (III) the maturation 


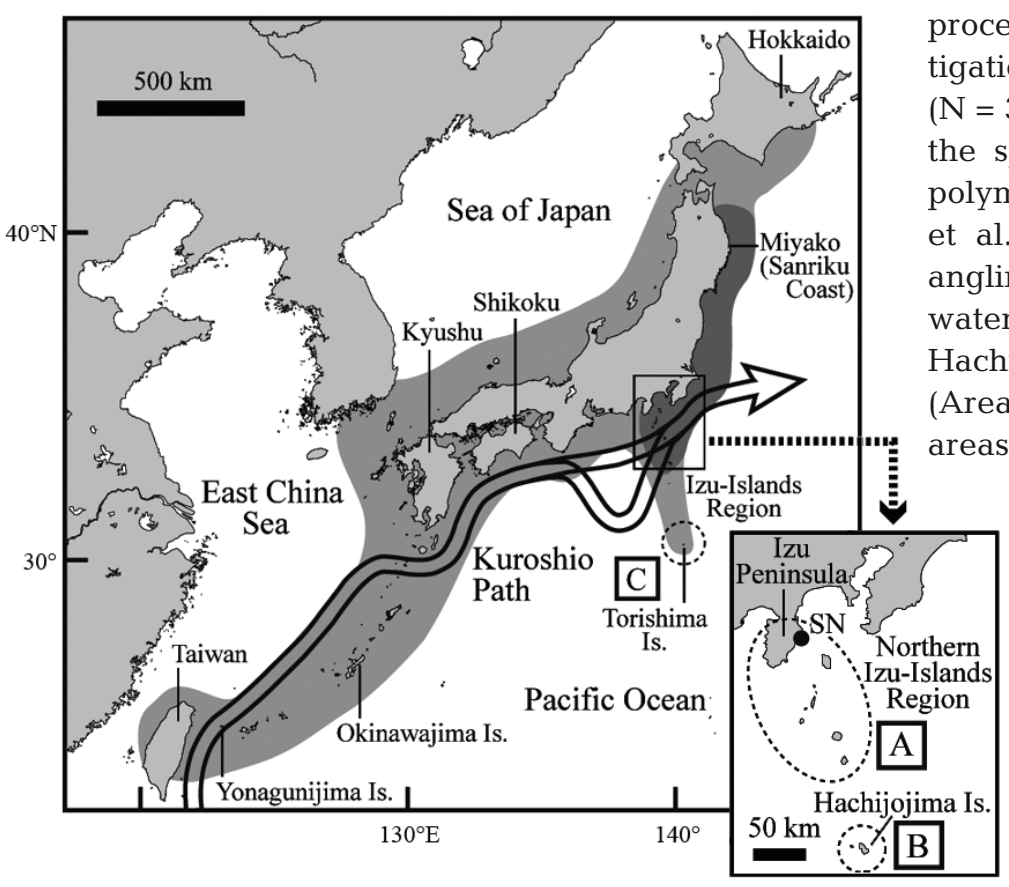

Fig. 1. Study area showing the 3 regions (dotted circles) where gnomefish were collected: (A) in the coastal waters of the northern Izu Islands, (B) Hachijojima Island, and (C) Torishima Island. The young for Investigation II were sampled at a set-net station ( $\mathrm{SN}$, solid circle). The distribution of gnomefishes in the northwestern Pacific Ocean are shaded gray according to Itoi et al. (2010). Scombrops boops is found in the overall gray zones, whereas $S$. gilberti is found in the dark gray zone only process of the gonads of adult gnomefish. For Investigation I, we collected different-sized gnomefish $(\mathrm{N}=367$ ) from May 2007 to July 2008 and identified he species using PCR-restriction fragment length polymorphism (PCR-RFLP) of mtDNA, based on Itoi et al. (2008) (Table 1). The fish were caught by angling, trawling and set-net fisheries in the coastal waters of the northern Izu-Islands region (Area A), Hachijojima Island (Area B), and Torishima Island (Area C) (Fig. 1). We divided the study area into 3 reas on the basis of the positional relation to the Kuroshio Current, since recent genetic studies have suggested that the transport of eggs and planktonic larvae by the Kuroshio Current might be a determining factor for the geographical distributions of the 2 gnomefishes (Itoi et al. 2011, Noguchi et al. 2012). Areas A and B are located in the main region and the southern margin of the Kuroshio Current, respectively, while Area $\mathrm{C}$ is about $300 \mathrm{~km}$ south of the Kuroshio region. The fish caught by angling and trawling were mostly collected from a depth zone of 150 to $600 \mathrm{~m}$. A set-net is a type of fixed fishing gear which compels fish to swim into a bag net located in the innermost chamber. Portions of the results from Investigation I (May 2007 to January 2008) have

Table 1. The total number (N) of gnomefish collected from the Izu-Islands region from May 2007 to July 2008, and the number (n) and range of standard lengths (SL, $\mathrm{mm}$ ) of Scombrops boops and $S$. gilberti identified by PCR-restriction fragment length polymorphism (PCR-RFLP) of mtDNA

\begin{tabular}{|c|c|c|c|c|c|c|c|c|c|}
\hline \multirow[t]{3}{*}{ Month } & \multirow[t]{3}{*}{$\mathrm{N}$} & \multicolumn{4}{|c|}{ S. boops } & \multirow{2}{*}{\multicolumn{3}{|c|}{ S. gilberti- }} & \multirow[b]{2}{*}{ _ Male } \\
\hline & & & -Female & 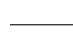 & _ Male & 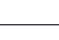 & & 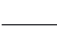 & \\
\hline & & $\mathrm{n}$ & SL & $\mathrm{n}$ & SL & $\mathrm{n}$ & SL & $\mathrm{n}$ & SL \\
\hline \multicolumn{10}{|l|}{2007} \\
\hline May & 13 & 8 & $198.2-357.8$ & 5 & $207.4-338.4$ & 0 & - & 0 & - \\
\hline Jun & 48 & 16 & $215.3-489.0$ & 20 & $219.9-506.4$ & 5 & $422.0-466.7$ & 7 & $447.5-468.9$ \\
\hline Jul & 10 & 5 & $280.9-351.4$ & 5 & $251.9-485.3$ & 0 & - & 0 & - \\
\hline Aug & 39 & 25 & $214.9-290.0$ & 10 & $217.7-268.3$ & 1 & 487.7 & 3 & $485.7-510.0$ \\
\hline Sep & 23 & 7 & $285.4-327.0$ & 9 & $242.0-304.8$ & 3 & $456.6-482.7$ & 4 & $452.2-480.0$ \\
\hline Oct & 40 & 20 & $236.5-360.8$ & 20 & $234.8-365.2$ & 0 & - & 0 & - \\
\hline Nov & 25 & 11 & $186.4-396.6$ & 13 & $176.6-372.2$ & 1 & 571.5 & 0 & - \\
\hline Dec & 17 & 10 & $265.2-424.6$ & 7 & $252.1-561.0$ & 0 & - & 0 & - \\
\hline \multicolumn{10}{|l|}{2008} \\
\hline Jan & 17 & 7 & $305.3-526.0$ & 10 & $282.0-528.6$ & 0 & - & 0 & - \\
\hline Feb & 18 & 8 & $281.3-446.5$ & 9 & $277.0-334.6$ & 1 & 487.3 & 0 & - \\
\hline Mar & 18 & 10 & $297.6-483.3$ & 8 & $276.2-490.7$ & 0 & - & 0 & - \\
\hline Apr & 21 & 11 & $248.6-494.5$ & 9 & $241.8-352.5$ & 1 & 433.2 & 0 & - \\
\hline May & 41 & 23 & $200.1-406.8$ & 16 & $197.5-344.0$ & 0 & - & 2 & $466.2-501.3$ \\
\hline Jun & 15 & 4 & $211.7-333.2$ & 5 & $209.8-353.3$ & 2 & $493.5-530.8$ & 4 & $426.3-492.5$ \\
\hline Jul & 22 & 11 & $215.2-443.4$ & 10 & $203.2-455.0$ & 1 & 426.1 & 0 & - \\
\hline Total & 367 & 176 & $186.4-526.0$ & 156 & $176.6-561.0$ & 15 & $422.0-571.5$ & 20 & $426.3-510.0$ \\
\hline
\end{tabular}


already been reported by Itoi et al. (2010). Here, we present new results from Investigation I.

For Investigation II, we sampled young gnomefish every month from a fishing boat at a set-net station in the coastal waters of the eastern Izu Peninsula, from May 2009 to June 2010 (Stn SN in Fig. 1, Table 2). The set-net had a bag net mesh size of 15 to $30 \mathrm{~mm}$, and was laid at a depth of 5 to $50 \mathrm{~m}$. A total of 289 young were collected throughout the sampling period. For Investigation III, a total of 70 gnomefish caught by angling were collected from the coastal waters of the northern Izu-Islands region and Hachijojima Island from November 2009 to May 2010 (Fig. 1, Table 3). We collected 10 adults every month except in April and May 2010. Only 7 fish were obtained in April, and therefore 3 additional fish were collected in May so as to total 20 fish during April and May. In Investigations II and III, we also used PCRRFLP on the mtDNA to identify the species.

Mochizuki (1977) inferred that the spawning season of gnomefish in the coastal waters of eastern Japan is December to April for $S$. boops and March to May for $S$. gilberti, based on seasonal variations in the gonadosomatic index (GSI). Therefore, we collected the adults between November and May to examine the maturation process for Investigation III.

All specimens in Investigations I to III were measured to the nearest $0.1 \mathrm{~mm}$ standard length (SL).

Table 2. Total number $(\mathrm{N})$ and range of standard lengths (SL, $\mathrm{mm}$ ) of young gnomefish collected monthly by the set-net sampling in the coastal waters of the eastern Izu Peninsula from May 2009 to June 2010, and the number of Scombrops boops and $S$. gilberti identified by PCR-restriction fragment length polymorphism (PCR-RFLP) of mtDNA

\begin{tabular}{|lcccc|}
\hline Month & N & SL & S. boops & S. gilberti \\
\hline 30 May 09 & 42 & $47.8-119.8$ & 42 & 0 \\
26 Jun 09 & 38 & $70.0-134.6$ & 38 & 0 \\
29 Jul 09 & 16 & $100.3-145.6$ & 16 & 0 \\
19 Aug 09 & 50 & $79.2-139.7$ & 50 & 0 \\
18 Sep 09 & 3 & $115.2-122.6$ & 3 & 0 \\
15 Oct 09 & 28 & $132.2-164.2$ & 28 & 0 \\
26 Nov 09 & 16 & $127.4-174.9$ & 16 & 0 \\
20 Dec 09 & 0 & - & - & - \\
14 Jan 10 & 11 & $163.2-175.6$ & 11 & 0 \\
17 Feb 10 & 0 & - & - & - \\
15 Mar 10 & 0 & - & - & - \\
22 Apr 10 & 0 & - & - & - \\
27 May 10 & 50 & $57.6-106.1$ & 50 & 0 \\
20 Jun 10 & 35 & $78.6-121.0$ & 35 & 0 \\
Total & 289 & $47.8-175.6$ & 289 & 0 \\
\hline
\end{tabular}

Table 3. Total number (N) and range of standard lengths (SL, $\mathrm{mm}$ ) of adult gnomefish collected from the Izu-Islands region from November 2009 to March 2010, and the number of Scrombrobs boops and $S$. gilberti identified by PCR-restriction fragment length polymorphism (PCR-RFLP) of mtDNA

\begin{tabular}{|lcccc|}
\hline Month & N & SL & S. boops & S. gilberti \\
\hline $\mathbf{2 0 0 9}$ & & & & \\
Nov & 10 & $435.1-567.0$ & 5 & 5 \\
Dec & 10 & $493.4-576.1$ & 5 & 5 \\
& & & & \\
2010 & & & & 5 \\
Jan & 10 & $444.1-615.3$ & 5 & 3 \\
Feb & 10 & $426.3-526.6$ & 7 & 5 \\
Mar & 10 & $464.9-572.2$ & 5 & 0 \\
Apr & 7 & $440.4-675.7$ & 7 & 9 \\
May & 13 & $481.0-625.1$ & 4 & 32 \\
Total & 70 & $426.3-675.7$ & 38 & \\
\hline
\end{tabular}

\section{DNA extraction and PCR amplification}

A small portion of skeletal muscle was excised from every individual. Total genomic DNA was extracted from the muscle using the method of Sezaki et al. (1999). Partial fragments of 16S rRNA gene on mtDNA were amplified by PCR using the primers 16SAR-L (5'-CGC CTG TTT ATC AAA AAC AT-3') and ftRLeu_R (5'-CTG TTB RAA GGG CTT AGG BCT TTT GC-3'), following Palumbi et al. (1991) and Itoi et al. (2007) respectively. PCR amplification was done in a $20 \mu \mathrm{l}$ reaction mixture containing genomic DNA as template, $4.0 \mu \mathrm{l}$ of 5× GoTaq DNA polymerase buffer, $0.8 \mu \mathrm{l}$ of $10 \mu \mathrm{M}$ primers, $2.0 \mu \mathrm{l}$ of $2 \mathrm{mM}$ dNTP and 1 unit of GoTaq DNA polymerase (Promega). The thermal cycling profile for the PCR consisted of initial denaturation at $94^{\circ} \mathrm{C}$ for 3 min followed by 40 cycles of denaturation at $94^{\circ} \mathrm{C}$ for $15 \mathrm{~s}$, annealing at $50^{\circ} \mathrm{C}$ for $20 \mathrm{~s}$ and extension at $72^{\circ} \mathrm{C}$ for $45 \mathrm{~s}$.

\section{PCR-RFLP}

The PCR conditions employed for RFLP analysis were the same as described above. PCR products for the 16S rRNA gene of the gnomefish were digested with 10 units of restriction enzymes EcoNI (New England Biolabs; www.neb.com) and MvaI (Toyobo; www.toyobo.co.jp) in a $10 \mu \mathrm{l}$ mixture containing $1.0 \mu \mathrm{l}$ of $10 \times$ buffer supplied with the kit and $5.0 \mu \mathrm{l}$ of PCR products. The digested products were electrophoresed on a $3 \%$ agarose gel and visualized with ethidium bromide. 


\section{Sequencing of PCR products}

When an individual could not be identified to species by the PCR-RFLP analysis, the PCR products were sequenced for both strands with a 3130xl Genetic Analyzer (Applied Biosystems) using a BigDye Terminator v3.1 Cycle Sequencing Kit (Applied Biosystems). Alignment of partial sequences of the $16 \mathrm{~S}$ rRNA gene for the gnomefishes obtained in this study was carried out using CLUSTAL W (Thompson et al. 1994).

\section{Analysis of maturation process}

The 70 adults collected in Investigation III were analyzed to study the maturation of the gonads. Gonads were extracted from the specimens by dissection, weighed to the nearest $0.1 \mathrm{~g}$ (wet weight), and fixed in $10 \%$ formalin. According to Mochizuki (1977), the GSI was calculated for both sexes by means of the following formula: GSI $=\left(\mathrm{GW} / \mathrm{SL}^{3}\right) \times$ $10^{7}$, where GW = gonad weight $(\mathrm{g})$ and $\mathrm{SL}=$ standard length $(\mathrm{mm})$. Generally, the GSI value increases with the development of the gonad. Mochizuki (1977) reported maximum GSI values of 68.3 for females and 35.5 for males (both values for $S$. gilberti).

Tissue preparation for the gonads of 70 adults in Investigation III was done using 2 methods: the paraffin sectioning method and the frozen section method. We used the paraffin sectioning method for 56 individuals with low GSI values $(<20)$, and the frozen section method for 14 individuals with high GSI values ( $\geq 20)$, since it is too difficult to retain the shape of developed germ cells ( $\geq 20$ in GSI) by the paraffin sectioning method. In the paraffin sectioning method, the fixed tissues were embedded in paraffin (mp 56 to $58^{\circ} \mathrm{C}$ ), serially sectioned to $5 \mu \mathrm{m}$ thickness, and stained with hematoxylin and eosin for microscopic observation. In the frozen section method, the fixed tissues were frozen at $-80^{\circ} \mathrm{C}$ in hexane and dry ice, and serially sectioned to $4 \mu \mathrm{m}$ thickness. The slices were placed on adhesive films (Kawamoto 2003) and stained with hematoxylin and eosin. We observed several parts of each gonad using light microscopes to identify the level of maturation.

\section{Statistical analysis}

For Investigations I and III, the distributions of SL were compared among groups using the KruskalWallis test, followed by Dunn's multiple comparisons test for the post-hoc analysis in Investigation I. The GSI values in Investigation III were also compared among groups using the Kruskal-Wallis test, followed by Dunn's multiple comparisons test. All statistical analyses were performed using Prism 4.0c (GraphPad Software).

\section{RESULTS}

\section{Species compositions}

The PCR-RFLP analysis of mtDNA showed that both Scombrops boops and S. gilberti were included in the gnomefish collected from May 2007 to July 2008, except for 18 individuals from the waters of Torishima Island (Table 1, Fig. 2). The collected fish consisted of $256 S$. boops and 27 S. gilberti from the northern Izu-Islands waters (Area A), 58 S. boops and 8 S. gilberti from the Hachijojima-Island waters (Area B) and $18 S$. boops only from the Torishima-Island waters (Area C). Torishima Island is located about $480 \mathrm{~km}$ away from the Izu Peninsula, and catching gnomefish is rare in this area. Therefore, we obtained 18 specimens in March 2008 only.

Body size distribution was markedly different between the 2 species (Table 1, Fig. 2). The body size of $S$. boops showed a wide variation, ranging from 176.6 to $561.0 \mathrm{~mm} \mathrm{SL}$, whereas all $S$. gilberti individuals were larger than $422.0 \mathrm{~mm} \mathrm{SL}$, with a maximum of $571.5 \mathrm{~mm}$ SL. The SL was significantly different among 4 groups (i.e. the females and the males of each species) (Kruskal-Wallis test, $H=81.82$, $\mathrm{p}<$ 0.0001). According to Dunn's multiple comparisons test, significant differences were found for every combination of $S$. boops and $S$. gilberti irrespective of sex ( $p<0.001$ for every combination), whereas intraspecific sexual differences were not significant for either species $(p>0.05)$.

Small individuals of $S$. gilberti $(<400 \mathrm{~mm}$ SL) were not collected by set-net sampling (Table 2); all 289 young fish collected during the period from May 2009 to June 2010, ranging in size from 47.8 to $175.6 \mathrm{~mm} \mathrm{SL}$, were identified as $S$. boops by the PCRRFLP analysis of mtDNA. Young fish were collected on most sampling days from May to November, but not from December to April (except for 11 individuals in January).

The adults collected from November 2009 to May 2010 consisted of 6 individuals of $S$. boops and $29 S$. gilberti from the northern Izu-Islands waters (Area A), as well as 32 individuals of $S$. boops and $3 S$. gilberti from the Hachijojima Island waters (Area B), 

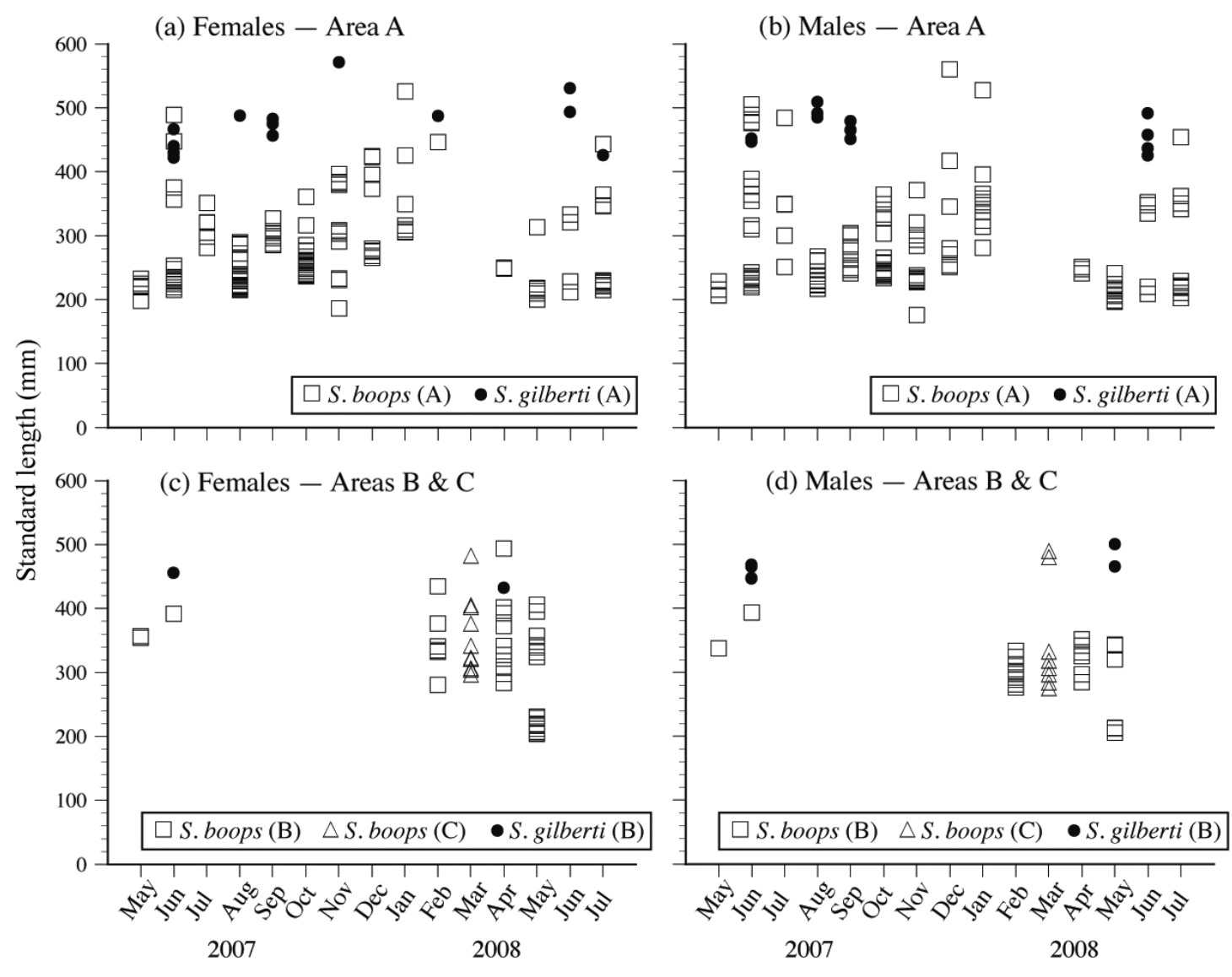

Fig. 2. Distributions of standard length $(\mathrm{mm})$ of gnomefishes Scrombrobs boops and S. gilberti collected from May 2007 to July 2008 (Investigation I). (a) Females from the northern Izu-Islands waters (Area A); (b) males from Area A; (c) females from the Hachijojima-Island waters (Area B) and the Torishima-Island waters (Area C); (d) males in Areas B and C. Results from Areas B and C are graphed together to minimize the number of panels (due to smaller sample sizes), since data from these areas do not overlap

as shown by the PCR-RFLP analysis of mtDNA (Table 3). The SL of the adults ranged from 434.3 to $601.1 \mathrm{~mm}$ for females and 426.3 to $675.7 \mathrm{~mm}$ for males of $S$. boops, and from 464.9 to $612.1 \mathrm{~mm}$ for females and 435.1 to $567.0 \mathrm{~mm}$ for males of $S$. gilberti. There was no significant difference in the SL among the females and males of each species (Kruskal-Wallis test, $H=5.455, \mathrm{p}>0.05$ ).

\section{GSI}

The GSI values of the different-sized gnomefish collected in Investigation I (May 2007 to July 2008) ranged from 0.0 to 3.0 for $S$. boops and 0.4 to 24.0 for $S$. gilberti. Relatively high GSI values of $>20$ were found for 2 female $S$. gilberti caught in April 2008 (24.0) and February 2008 (20.5); all other gnomefish showed low GSI values of $\leq 5.1$.

The GSI values of the adult gnomefish collected in Investigation III (November 2009 to May 2010) were markedly different between the species in both the northern Izu-Islands waters and the Hachijojima Island waters (Fig. 3). The GSI of $S$. boops ranged from 0.2 to 3.0 except for one male (12.4) from the Hachijojima Island waters. By contrast, many individuals of $S$. gilberti showed high GSI values of $\geq 20$ ( 9 females and 5 males). The difference in GSI was significant among the females and males of each species (Kruskal-Wallis test, $H=$ 48.23, $\mathrm{p}<0.0001)$. According to Dunn's multiple comparison test, significant differences $(p<0.001)$ were found for every combination of $S$. boops and $S$. gilberti, irrespective of sex, except between $S$. gilberti males and $S$. boops females $(\mathrm{p}<0.01)$. No intraspecific sexual differences were found for either species $(p>0.05)$.

The GSI values of $S$. gilberti were elevated from November to March in both females and males (Fig. 3). The highest values were found in March (females, 47.6; males, 36.6), which subsequently decreased, with a range of 3.7 to 33.3 in May. 

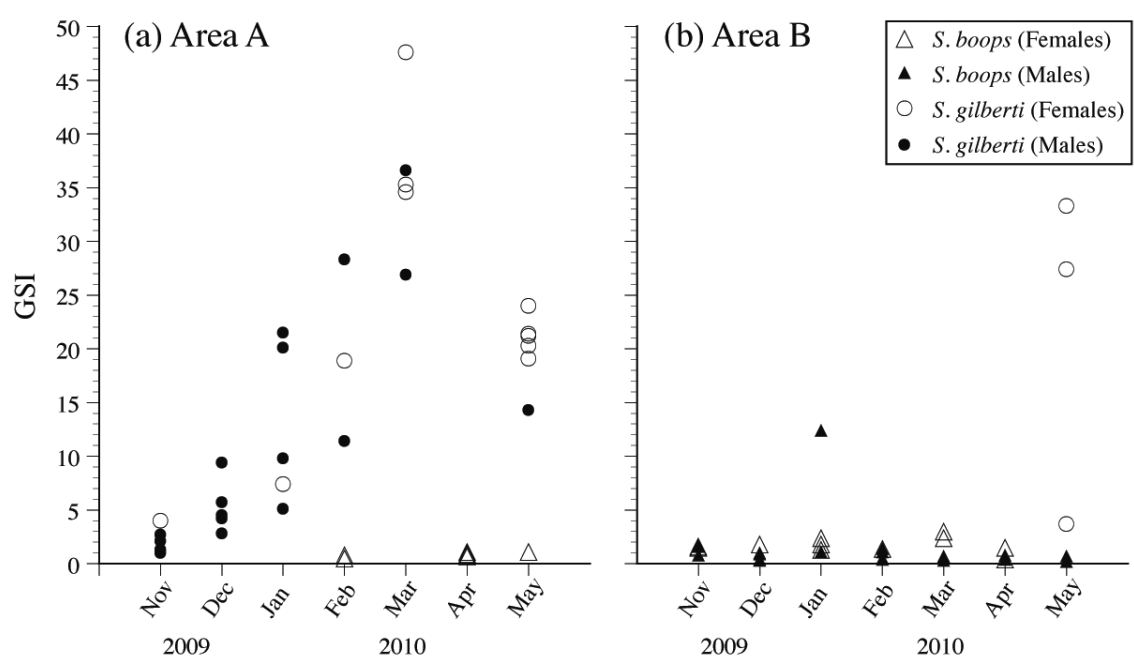

Fig. 3. Monthly changes in gonadosomatic index (GSI) of adult gnomefishes Scrombrobs boops and S. gilberti from (a) the northern Izu-Islands waters (Area A), and (b) the Hachijojima-Island waters (Area B)

\section{Oogenesis}

Oocytes were found to vary in size and form in the ovaries of the adult $S$. gilberti collected from November 2009 to May 2010 (Fig. 4). In the present study, the oocytes were classified into 7 stages (O1-O7), mainly referring to Takano (1989): chromatin-nucleolus stage $(\mathrm{O} 1)$, perinucleolus stage $(\mathrm{O} 2)$, yolk vesicle stage (O3), oil droplet stage (O4), vitellogenic stage (O5), migratory nucleus stage (O6) and maturation stage (O7).

At the beginning of oogenesis (Stage O1), the size of the nucleoli in the nucleus increases slightly (Fig. 4a); by Stage O2, the nucleoli are located at the periphery of the nucleus (Fig. 4a). In the next phase, yolk vesicles appear in the cytoplasm (O3, Fig. 4a) and subsequently, oil droplets surround the nucleus (O4, Fig. 4b). In Stage O5, yolk globules appear in the cytoplasm and the oil droplets are scattered throughout the cytoplasm (Fig. 4c). Maturation of the oocyte leads to the migration of the nucleus toward the animal pole at Stage O6 (Fig. 4d), and finally to the disappearance of the nucleus, and the conglomeration of the oil droplets at Stage O7 (Fig. 4e).

We identified the maturation levels for the respective females on the basis of the oocytes at the most advanced stage. The maturation levels of female $S$. boops were identified to be at the early stages (from $\mathrm{O} 2$ to $\mathrm{O} 4$ in almost all individuals), except for one female that was categorized as O6 (Fig. 5). This exceptional female showed a markedly low GSI value of 3.0, and its ovary included various oocytes at different stages, from primary oocytes to apparently regressed oocytes posterior to maturation.

By contrast, the ovaries of $S$. gilberti included mature oocytes at stages $\mathrm{O} 6$ and $\mathrm{O} 7$ in 8 of 14 females (Fig. 5). These mature females were collected in March and May (no $S$. gilberti were found in the adult gnomefish collected in April). The GSI of the female $S$. gilberti appeared to peak in March as mentioned above, whereas mature oocytes were more frequently found in May (Fig. 5).

\section{Spermatogenesis}

In the present study, spermatogenesis was classified into 6 stages (T1 to T6), mainly referring to Takahashi (1989) and Asahina et al. (1980): growth stage (T1), growth-maturation stage (T2), functional maturation stage (T3), maturation-post-spawn stage (T4), post-spawn stage (T5), and testicular quiescent stage (T6) (Fig. 6).

During Stage T1, seminal lobules are filled with spermatocytes by the growth of spermatogonia (Fig. 6a). In Stage T2, the amount of spermatids and sperm increases (Fig. 6b), and the seminal lobules are filled with sperm at Stage T3 (Fig. 6c). The amount of sperm decreases during Stage T4, and empty spaces become conspicuous in the seminal lobules (Fig. 6d). Sperm still remains at Stage T5, but the empty space increases and the walls bordering the cysts thicken (Fig. 6e). Eventually, the sperm almost completely disappears at Stage T6 (Fig. 6f).

In contrast to the ovaries, the testes of $S$. boops were identified to be mature (Stages T2 to T4) in as many as 8 males (Fig. 7). In particular, the male with a relatively high GSI value of 12.4 was identified to be in functional maturation Stage T3, generally regarded as the most mature stage (Takahashi 1989). In addition, immature testes at Stages T5 and T6, characterized as regressed testes, were also found in 7 $S$. boops individuals.

On the other hand, all the testes of $S$. gilberti were identified as T1 and T2 only (Fig. 7). Five males with relatively high GSI values of 11.4 to 36.6 , collected between February and May, were all identified as T2. 

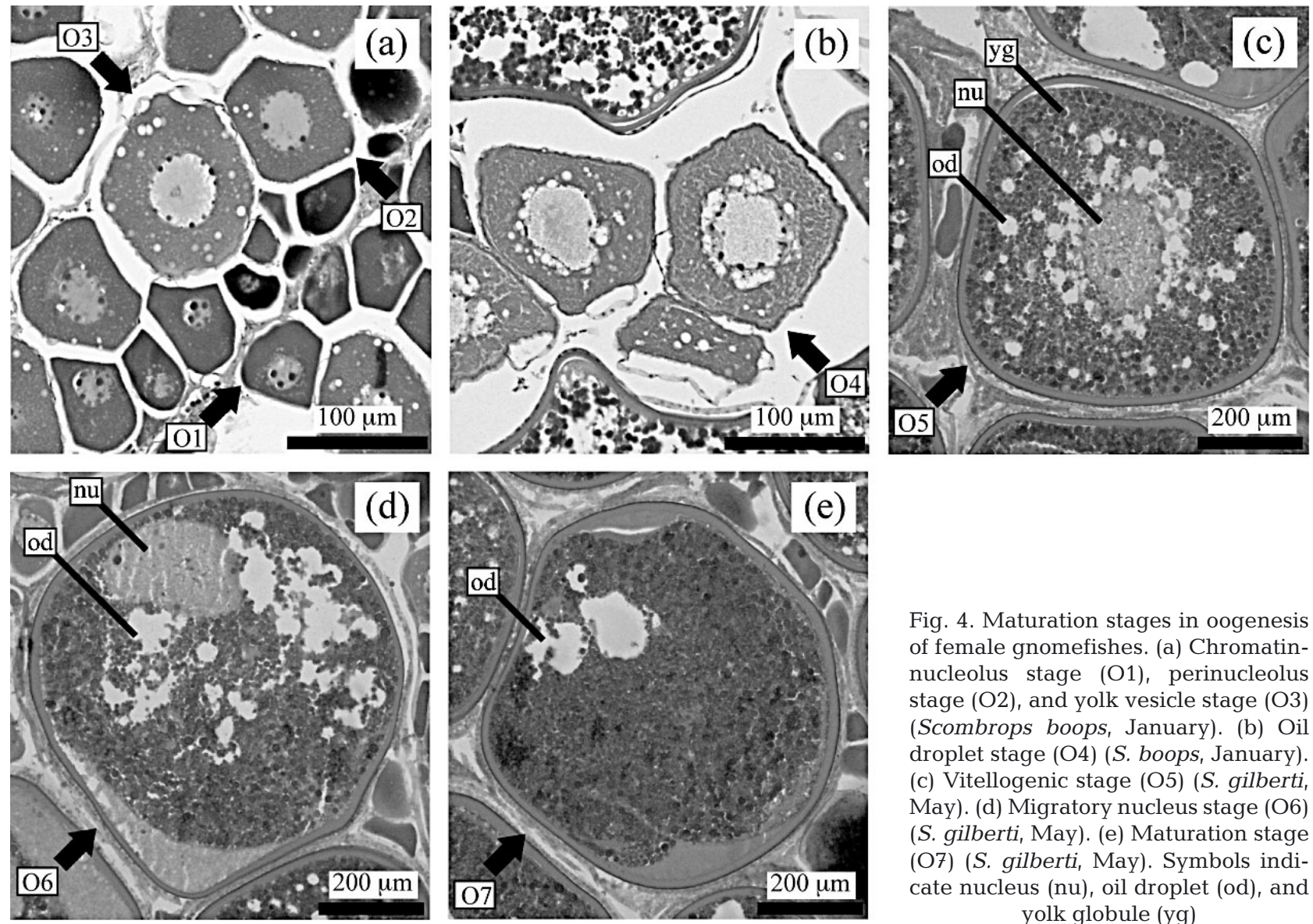

Fig. 4. Maturation stages in oogenesis of female gnomefishes. (a) Chromatinnucleolus stage (O1), perinucleolus stage $(\mathrm{O} 2)$, and yolk vesicle stage $(\mathrm{O} 3)$ (Scombrops boops, January). (b) Oil droplet stage (O4) (S. boops, January). (c) Vitellogenic stage (O5) (S. gilberti, May). (d) Migratory nucleus stage (O6) (S. gilberti, May). (e) Maturation stage (O7) (S. gilberti, May). Symbols indicate nucleus (nu), oil droplet (od), and yolk globule (yg)

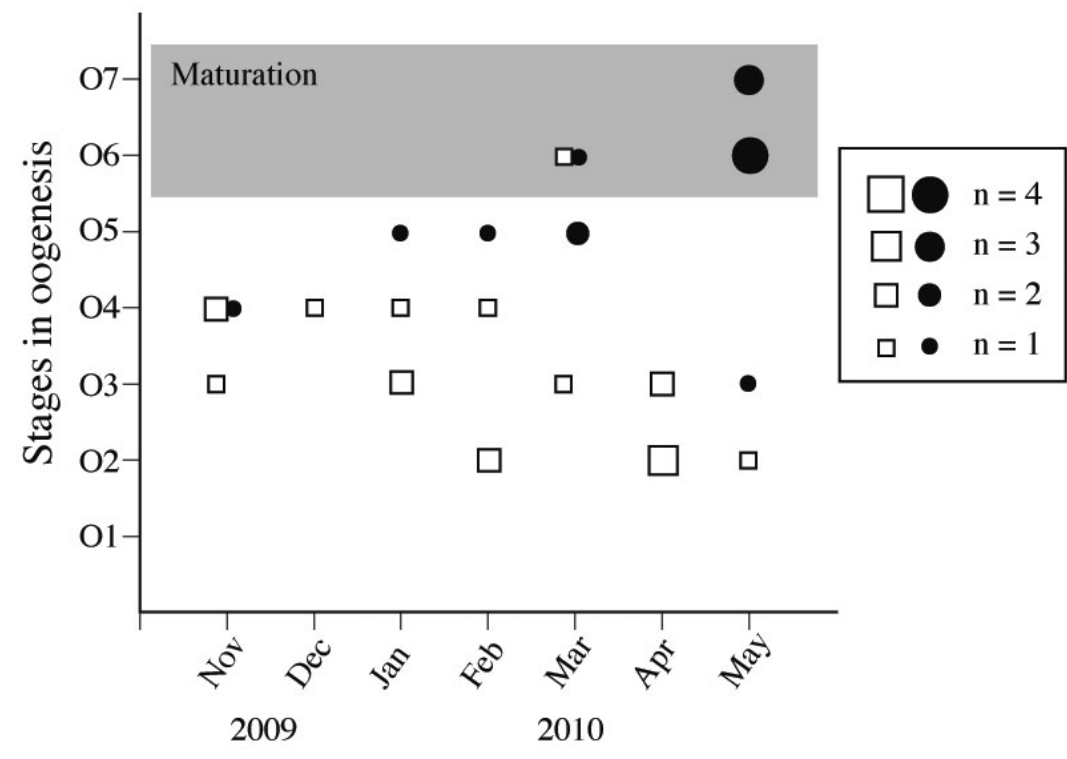

Fig. 5. Monthly changes in the stages of oogenesis for Scombrops boops () and S. gilberti (@) from Nov 2009 to May 2010. The size of the open squares and solid circles reflects the number of individuals at each stage

\section{DISCUSSION}

\section{Habitat use in the Izu-Islands region}

The gnomefish collected from May 2007 to July 2008 consisted of $332 S$. boops, and only $35 \mathrm{~S}$. gilberti (Investigation I, Table 1). It is noteworthy that all $35 S$. gilberti were large (>400 $\mathrm{mm} \mathrm{SL})$, whereas $S$. boops showed a wide range in SL (Fig. 2). Furthermore, during the set-net sampling between May 2009 and June 2010, 289 young gnomefish were collected, all of which were $S$. boops (i.e. no young $S$. gilberti were collected; Investigation II, Table 2). Previous genetic studies of gnomefish in the Izu-Islands region have reported that almost all the small gnomefish $(<400 \mathrm{~mm}$ SL) were identified as $S$. boops (Itoi et al. 2008, 2010), but little is known about seasonal variations in species composition of the young in the region. 

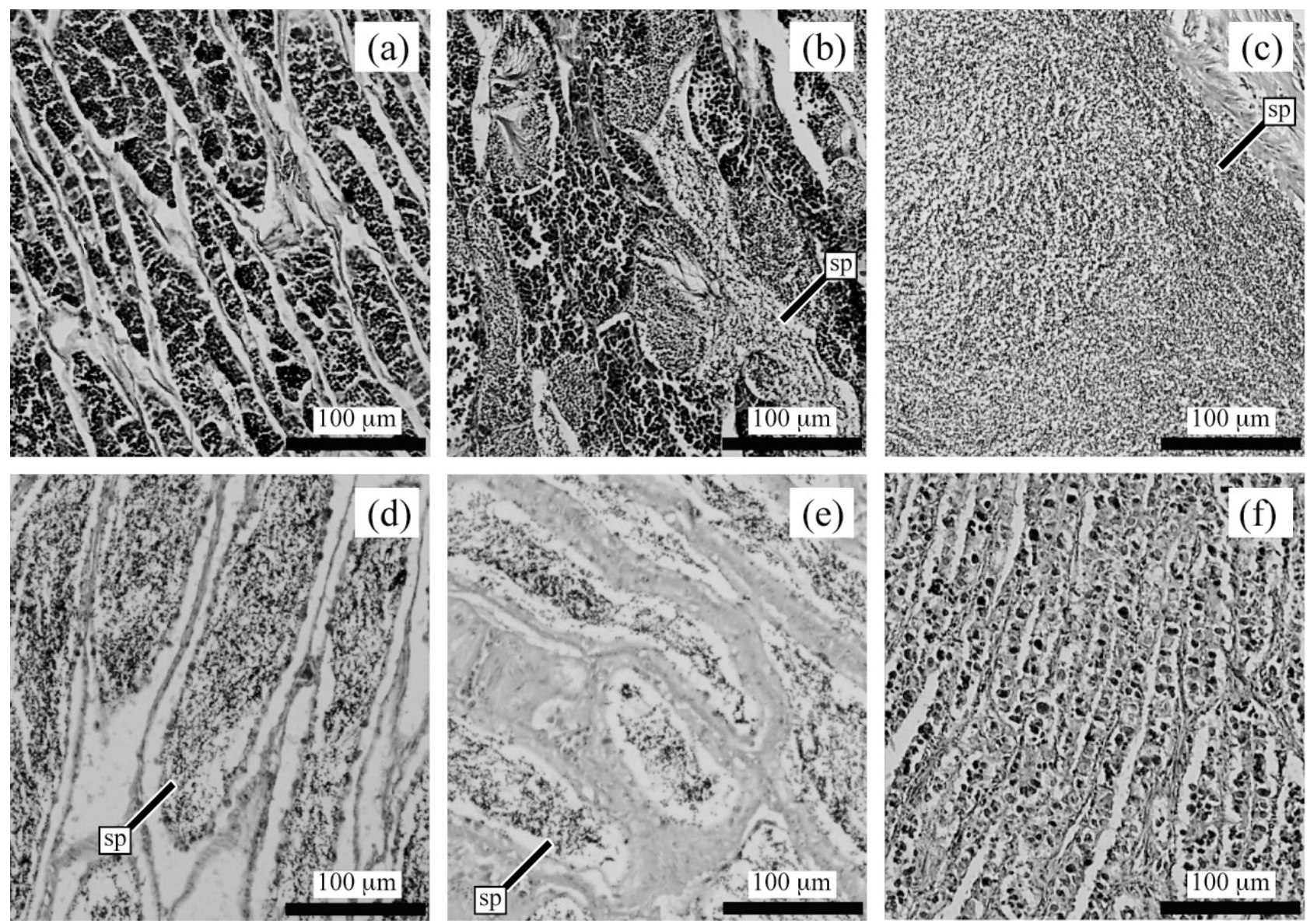

Fig. 6. Maturation stages in spermatogenesis of male gnomefishes. Spermatogenesis was classified into 6 stages: (a) growth stage (T1, Scombrops gilberti, December), (b) growth-maturation stage (T2, S. boops, December), (c) functional maturation stage (T3, S. boops, January), (d) maturation-post-spawn stage (T4, S. boops, March), (e) post-spawn stage (T5, S. boops, March), and (f) testicular quiescent stage (T6, S. boops, May). Sperm is indicated by the symbol (sp)

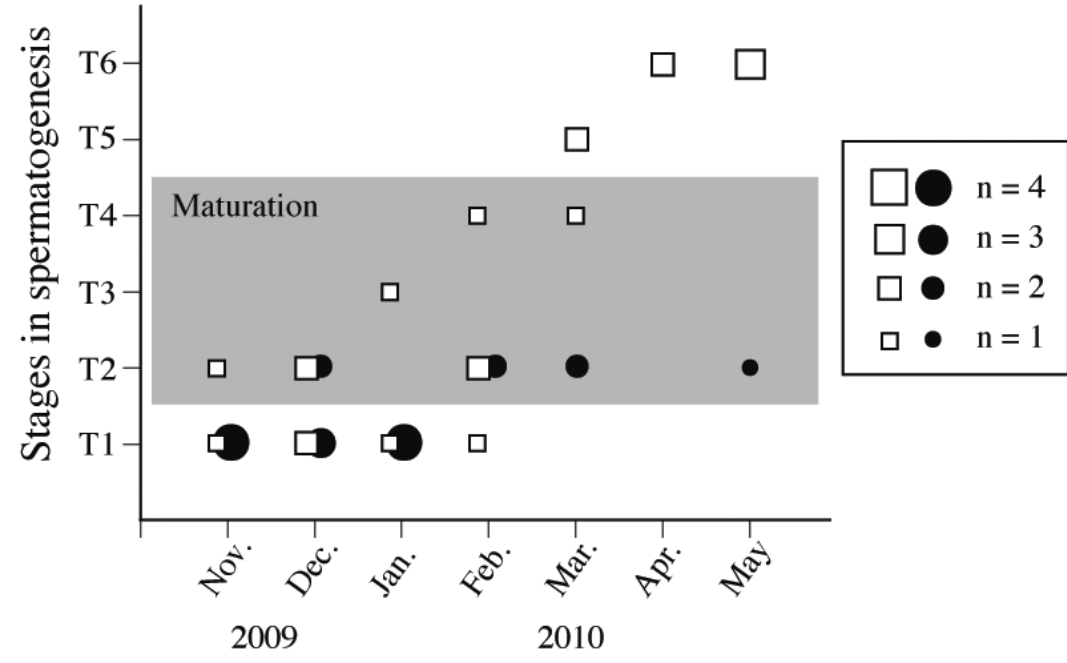

Fig. 7. Monthly changes in the stage of spermatogenesis for Scombrops boops ( $\square$ ) and S. gilberti ( from Nov 2009 to May 2010. The size of the open squares and solid circles reflects the number of individuals at each stage
The year-round results in the present study demonstrate that only $S$. boops is present in the Izu-Islands region in young and immature stages. In other words, only $S$. boops utilizes this region as a nursery.

The GSI values of the gnomefish collected from November 2009 to May 2010 were markedly different between $S$. boops and $S$. gilberti, for both females and males (Investigation III, Fig. 3). All 5 individuals of $S$. gilberti collected in March showed high GSI values of 26.9 to 47.6 , whereas all $S$. boops individuals showed low GSI values (ranging from 0.4 to 3.0 in females and 0.2 to 12.4 in males). The results of the histological observations of the ovaries were consistent with the seasonal variation in GSI. The ovaries of $S$. gilberti were identified as mature (Stages $\mathrm{O} 6$ and O7) in 8 
females collected between March and May (Fig. 5). It appears that the mature ovaries of $S$. gilberti frequently occurred in May, posterior to the peak in the GSI. In contrast, the ovaries of $S$. boops were identified as immature (Stages O2 to O4), except for one female that had some mature oocytes at Stage O6, and an abundance of immature oocytes at Stages O2 and O3. This exceptional ovary was extracted from a female with a markedly low GSI value of 3.0, and it was inferred that this female had already completed spawning in this season. Yamada (1995) experimentally reared 79 young $S$. boops (150 to $170 \mathrm{~mm}$ in total length) caught in the northern Izu-Islands region in September 1989, and reported that 9 individuals survived until March 1994 in a concrete pond with a capacity of $50 \mathrm{~m}^{3}$, growing to 380 to $400 \mathrm{~mm}$ in total length. These individuals reportedly spawned in the pond 5 times between March 2 and 25. The result in this experimental study showed that $S$. boops can spawn at a size of $>400 \mathrm{~mm}$ SL in early spring. Accordingly, the low GSI values and immature ovaries in large $S$. boops ( $>400 \mathrm{~mm}$ SL) collected in the present study from November to May demonstrate that $S$. boops does not spawn in the Izu-Islands region. Only $S$. gilberti likely utilizes this region as a spawning ground in the spring, probably from March to May.

In contrast, the results of the histological observations of the testes were inconsistent with the seasonal variation in GSI (Fig. 7). Eight S. boops males had mature testes at Stages T2 to T4, in spite of having low GSI values ranging from 0.2 to 12.4 , compared with the higher GSI values of $>20$ in $S$. gilberti. This result suggests that the testes of $S$. boops in the IzuIslands region fully develop in the maturation process but do not increase in size. In any case, these male $S$. boops do not mate in the Izu-Islands region, since mature females of $S$. boops are likely absent from the region as mentioned above.

In $S$. gilberti, mature testes at Stage T2 occurred for half a year from December 2009 to May 2010 (Fig. 7). The T2 testes from fish collected in December showed low GSI values of 4.5 to 9.4, whereas the T2 testes during February to May showed high GSI values of 11.4 to 36.6. It appears that the testes of $S$. gilberti increased in size during the T2 stage. We are unable to make a generalization about the maturation process of male $S$. gilberti in April and May, since only one male $S$. gilberti was found among the adult gnomefish collected during this study period. In future studies, it would be necessary to collect and analyze more males of $S$. gilberti in that season.

\section{The nursery ground for $S$. gilberti}

In the present study, no small $S$. gilberti $(<400 \mathrm{~mm}$ $\mathrm{SL})$ were collected in the Izu-Islands region, results that are similar to previous studies (Tables 1 \& 2; Itoi et al. 2008, 2010). This indicates that most eggs and planktonic larvae born in the region are transported to other, distant locations. They are likely transported to the Sanriku region in northeastern Japan by the Kuroshio Current and its warm-core rings, and subsequently settle on the sublittoral bottom as inferred by Itoi et al. (2011). On 8 June 2012, a juvenile gnomefish with $32.4 \mathrm{~mm}$ SL was seined in a seagrass bed in Miyako Bay in the Sanriku region, and subsequently identified as $S$. gilberti by mtDNA sequencing (S. Itoi unpubl. data). Itoi et al. (2010) reported that 106 young $S$. gilberti (106 to $181 \mathrm{~mm}$ SL), genetically identified, were collected off the Miyako Bay from 18 September to 21 November 2008. Thus, this paper suggests that (1) adult $S$. gilberti spawn in spring (March to May) in the IzuIslands region, and (2) young $S$. gilberti grow in the nursery of the Sanriku region between summer and autumn after being transported there by the Kuroshio Current.

\section{Spawning ground of $S$. boops}

In this study, mature $S$. boops adults with high GSI values were not found in the Izu-Islands region (Fig. 3). Mochizuki (1977) suggested that $S$. boops spawn from December to April in the coastal waters of eastern Japan, and from October to February in the coastal waters of western Japan, based on seasonal variations in the GSI of the gnomefish collected from a broad area on the Pacific side. However, the maximum GSI values of $S$. boops reported by Mochizuki (1977) were 24.3 for females and 18.2 for males, much lower than the GSI values of $S$. gilberti, with a maximum of 68.3 for females and 35.5 for males in the same study, and 47.6 and 36.6 for females and males, respectively, in the present study. The ovaries of $S$. boops collected by Mochizuki (1977) were likely immature.

In early December 2012, we collected an adult $S$. boops with a high GSI value of 30.2 from the coastal waters of the Yonagunijima Island in the southernmost shelf break of the East China Sea. We also collected 2 females with developed ovaries at Stage O6 in that month, although the GSI values from that individual were relatively low (11.1 to 16.8) (N. Takai unpubl. data). The Nansei Regional 
Fisheries Research Laboratory (1969) reported that planktonic larvae and juvenile $S$. boops were collected from late February to early March from the surface layer in the shelf break zone of the East China Sea. Thus, we expect that $S$. boops spawns in the region during the winter and are transported to the Izu-Islands region over a great distance. Consequently, the geographical differences in species-specific spawning grounds and in the current transport system likely determine the interspecific differences in the geographical distributions of $S$. boops and $S$. gilberti.

It is generally supposed that the shelf break of the East China Sea is the major spawning ground for many pelagic fishes and invertebrates, and that the warm currents of the Kuroshio Current and the Tsushima Warm Current transport eggs, larvae, and juveniles to the general area of the Japanese Archipelago on both sides: the Pacific Ocean and the Sea of Japan. Some examples are Pacific bluefin tuna Thunnus orientalis (Kitagawa et al. 2010), Japanese horse mackerel Trachurus japonicus, Yellowtail Seriola quinqueradiata (Ochiai \& Tanaka 1986) and Japanese common squid Todarodes pacificus (Okutani 1995). The reproductive strategy of $S$. boops appears to be exactly the same as that of these pelagic species, although the adult gnomefish is a mesopelagic fish inhabiting the layer 200 to $700 \mathrm{~m}$ deep. The shelf break of the East China Sea might be important for the reproductive strategy of mesopelagic fishes as well as that of many pelagic fishes.

Acknowledgements. We thank Akazawa-Gyogyo for their cooperation in set-net sampling of the fish. This study was financially supported by Research Grants for 2007 and 2008 from College of Bioresource Sciences, Nihon University.

\section{LITERATURE CITED}

Asahina K, Iwashita I, Hanyu I, Hibiya T (1980) Annual reproductive cycle of a bitterling, Rhodeus ocellatus ocellatus. Bull Jpn Soc Sci Fish 46:299-305

Hayashi M (2002) Scombropidae. In: Nakabo T (ed) Fishes of Japan with pictorial keys to the species, English edn. Tokai University Press, Tokyo, p 786

Itoi S, Saito T, Washio S, Shimojo M, Takai N, Yoshihara K, Sugita H (2007) Speciation of two sympatric coastal fish species, Girella punctata and Girella leonina (Perciformes, Kyphosidae). Org Divers Evol 7:12-19

Itoi S, Takai N, Naya S, Dairiki K and others (2008) Species identification method for Scombrops boops and Scombrops gilberti based on polymerase chain reactionrestriction fragment length polymorphism analysis of mitochondrial DNA. Fish Sci 74:503-510
Itoi S, Odaka J, Yuasa K, Akeno S and others (2010) Distribution and species composition of juvenile and adult scombropids (Teleostei, Scombropidae) in Japanese coastal waters. J Fish Biol 76:369-378

Itoi S, Odaka J, Noguchi S, Noda T and others (2011) Genetic homogeneity between adult and juvenile populations of Scombrops gilberti (Percoid, Scombropidae) in the Pacific Ocean off the Japanese Islands. Fish Sci 77: 975-981

Iwai T (2005) Introduction to ichthyology. KoseishaKoseikaku, Tokyo

Kawamoto T (2003) Use of a new adhesive film for the preparation of multi-purpose fresh-frozen sections from hard tissues, whole-animals, insects and plants. Arch Histol Cytol 66:123-143

Kitagawa T, Kato Y, Miller MJ, Sasai Y, Sasaki H, Kimura S (2010) The restricted spawning area and season of Pacific bluefin tuna facilitate use of nursery areas: a modeling approach to larval and juvenile dispersal processes. J Exp Mar Biol Ecol 393:23-31

Matsubara K (1971) Pomatomidae (Scombropidae). Fish morphology and hierarchy, Part 1. Ishizaki-Shoten, Tokyo

Mochizuki K (1977) Systematics, distribution, growth and reproduction of scombropid fishes. PhD dissertation, Tokyo University

Mochizuki K (1997) Scombropidae. In: Okamura O, Amaoka K (eds) Sea fishes of Japan. Yama-Kei Publishers, Tokyo, p 310

Muto S (1985) The coastal waters of the Sanriku region. II. Physical environment. In: Oceanographical Society of Japan (ed) Coastal Oceanography of Japanese Islands. Tokai University Press, Tokyo, p 220-231

- Noguchi S, Itoi S, Takai N, Noda T, Myojin T, Yoshihara K, Sugita H (2012) Population genetic structure of Scombrops boops (Percoid, Scombropidae) around the Japanese archipelago inferred from the cytochrome $b$ gene sequence in mitochondrial DNA. Mitochondrial DNA 23: 223-229

Ochiai A, Tanaka M (1986) Ichthyology, Vol 2. KoseishaKoseikaku, Tokyo

Okiyama M (1988) An atlas of the early stage fishes in Japan. Tokai University Press, Tokyo

Okutani T (1995) Cuttlefish and squids of the world in color. Okumura Printing, Tokyo

Palumbi S, Martin A, Romano S, McMillan WO, Stice L, Grabowski G (1991) The simple fool's guide to PCR, version 2. University of Hawaii, Honolulu, HI

Sezaki K, Begum RA, Wongrat P, Srivastava MP and others (1999) Molecular phylogeny of Asian freshwater and marine stingrays based on the DNA nucleotide and deduced amino acid sequences of the cytochrome $b$ gene. Fish Sci 65:563-570

Takahashi H (1989) Structure and gametogenesis of the testis. In: Takajima F, Hanyu I (eds) Suizoku-Hanshokugaku (Reproductive biology of aquatic animals). MidoriShobo, Tokyo, p 35-64

Takano K (1989) Structure and gametogenesis of the ovary. In: Takajima F, Hanyu I (eds) Suizoku-Hanshokugaku (Reproductive biology of aquatic animals). MidoriShobo, Tokyo, p 3-34

Tanaka S (1931) On the distribution of fishes in Japanese waters. J Fac Sci Tokyo Univ 4 3:1-90

Nansei Regional Fisheries Research Laboratory (1969) The summary of Shunyo-Maru Cruise for the marine biologi- 
cal research in the area between the southern Shikoku and eastern Taiwan. Nansei Regional Fisheries Research Laboratory, Kochi

Thompson JD, Higgins DG, Gibson TJ (1994) CLUSTAL W: improving the sensitivity of progressive multiple sequence alignment through sequence weighting, positionspecific gap penalties and weight matrix choice. Nucleic

Editorial responsibility: Christine Paetzold, Oldendorf/Luhe, Germany
Acids Res 22:4673-4680

Yamada T (1995) Spawning and hatching of Japanese scombropid Scombrops boops. Saibai Giken 23:145-146 (in Japanese)

Yasuda F, Mochizuki K, Kawajiri M, Nose Y (1971) On the meristic and morphometric differences between Scombrops boops and S. gilberti. Jpn J Ichthyol 18:118-124

Submitted: June 18, 2013; Accepted: May 12, 2014

Proofs received from author(s): June 21, 2014 